\title{
The teaching reform of art In architecture
}

\author{
Jiali Guo \\ Zhengzhou university Of industrial technology,Zhengzhou \\ Corresponding author Email:597128967@qq.com
}

Keywords: basic teaching of art, the reform of teaching, artistic accomplishment, ability of thinking

\begin{abstract}
Traditional architecture speciality based teaching of fine arts, the use of art techniques taught in the single teaching mode of thinking, ignoring the aesthetic ability, the fine arts foundation course should pay attention to the cultivation of the ability and performance ability. Firstly, this paper analyzes the existing problems of education in traditional art based on the current situation of art teaching in architecture. In view of existing problems, analysis of architecture art foundation teaching reform, mainly from the "clear positioning, rich practice teaching, expanding teaching form, modern education technology, correct teaching evaluation standard" five aspects in this paper, the concrete contents and feasibility of the reform measures. Architecture art foundation teaching reform in order to pay attention to visual art comprehensive qualities and creative thinking ability training as the goal, is a significant education education reform, helps to cultivate talents and the development of the discipline of architecture.
\end{abstract}

\section{Introduction}

There is an imbalance between perceptual thinking and rational thinking in the basic teaching concept of architecture in Chinese universities. Traditional architecture art foundation education system used for art painting techniques training mode, the lack of deep understanding of architectural art teaching, the lack of aesthetic sentiment and creativity, has violated the significance in the fine arts teaching in architecture professional discipline.

The present situation of the domestic arts foundation teaching can be summarized as "art = painting, painting = techniques", the classroom teaching method is given priority to with painting copy and sketch, through a lot of skill training to improve the students' ability of painting language expression. The basic teaching of art in traditional architecture is guided by the training of drawing skills, and emphasizes the training of drawing techniques and painting techniques. This kind of teaching model to some extent, has trained students perception of form, space, color and observing ability, but there are also some disadvantages, specifically embodied in the lack of students' creative thinking inspiration and guidance, formatting training program is difficult to compatible with innovative teaching ideas, ignoring the basic courses of fine arts in the role of architecture speciality training. Traditional art basic teaching relies too much on the analysis of rational theory knowledge, and neglects the cultivation of students' color and spatial perceptual ability.

The basic teaching of art in architecture aims at cultivating students' comprehensive quality and aesthetic ability, focusing on improving students' artistic perception and expression of space modeling and color expression. There is an essential difference between the art courses of architecture major and art courses, and the basic courses of architecture specialty should focus on the cultivation of students' creative thinking. Fine arts foundation course should be carried out according to the characteristics of the architecture speciality, in the teaching should not only pay attention to art skills, the ultimate goal is to learn by fine arts foundation education to teach students how to analyze the phenomenon of visual, rich visual experience. Let students acquire their own painting language expression in the basic course of art, develop students' intelligence and creative ability, and lay the foundation for the study of the professional knowledge of architecture. 


\section{Preliminary study on basic teaching reform of architecture speciality.}

\subsection{Course positioning}

Architecture art foundation course is a professional architecture professional talent training scheme of the basic required courses, the teaching goal should be to improve students' cognition and understanding of "beauty", to strengthen the experience of "art" and to use. Architecture art foundation courses not only undertake the education of subject ontology function, also carrying the continuation and development of corresponding to the discipline of education purpose, in terms of the fine arts foundation course, carries on the professional education of architecture. Fine arts foundation course of discipline education function of ontology embodied knowledge and skill training in art theory, art foundation course education significance in the study to architecture through the discipline of professional learning bring some thinking consciousness and penetration of meaning, to student's learning psychology, learning behavior, some positive touches. According to the function orientation and subject orientation of the course, the teaching reform is mainly carried out from the following three aspects.

Architecture is a comprehensive discipline covering a wide range of disciplines, and its professional basic courses and compulsory courses are more complex and abundant. The basic course of art can be allocated in the whole course system of architecture, and the foundation of art must be arranged according to the basic teaching purpose of architectural art. Combining with the characteristics of professional and architecture art foundation courses generally set up three major basic required courses: art foundation 1 (drawing), art foundation 2 (color), art foundation and technique (design sketch). The setting of three basic art courses conforms to the teaching law, and there is a close relationship between the courses, which has certain stability and continuity, and is gradual and easy to enter. Art foundation 1 ((drawing) focuses on training students' sense of space and shape and the expressive force of skills; Art foundation 2 (color) emphasizes the students' color harmony and the sensitivity of contrast relations; Art foundation 3 (design sketch) is to apply the basic knowledge of fine arts to the technical training in architectural design expression. In the teaching of basic art course, it is necessary to pay attention to the transformation of teaching concept, namely, the cultivation of the objective of the comprehensive teaching of aesthetics and accomplishment by pure technique training. In addition, the architecture speciality should also set up some basic specialized elective courses, such as art appreciation, the Chinese art history, foreign art history, etc., let the students should be more widely different genres of art, the art thoughts, ideas, understand art concept, enhance comprehensive artistic accomplishment. The expansion of students' knowledge can subtly influence the creativity, concept and conception of architectural design and lay an aesthetic foundation for the study of architectural design.

In architecture art education, we should reflect the mutual infiltration, mutual complementation and mutual promotion between the courses of knowledge, theory and method, instead of mutually exclusive, isolated and mutually closed way of thinking. To expand, discover and summarize problems. After the course integration, not only can we save time, but also make the course complete, vivid, profound and comprehensive. The setting of architecture specialty art curriculum must be integrated, so that students have comprehensive, complete professional knowledge and professional quality. Color courses, for example, in the architecture of color knowledge including design of two kinds of color, painting, color, basic knowledge in curriculum content embodied in colour, the use of color (color), the sketch content such as color, rendering techniques, in colour, building a preliminary, are involved in the architectural design course such as the teaching content. If these courses are implemented in a step-by-step manner, there will be duplication of content and chaos of order. Therefore, when the course content is determined, it is considered to decompose these contents and make the teaching content of color knowledge more systematic and scientific. Constantly in the process of the curriculum of infiltration or in different courses such as arts and crafts, photography, music appreciation, psychology, aesthetics, sociology and other there is the latest demand for professional courses and the latest ideas, this will help to develop student's visual cognition, broaden the field of vision, improve students' comprehensive quality, make it be able to use acquired 
knowledge interpretation, to discover the beauty in your life and the environment through appreciation and practice activities, improve the aesthetic ability, the analysis of the art ability, set up their own art values.

\subsection{Enriching practical teaching}

In the process of practice teaching, students can learn the theoretical knowledge of fine arts to real in-depth interpretation and understanding, strengthen the artistic sensibilities and expressive, the formation of aesthetic consciousness, improve their ability of creative thinking. Sketch training courses is an important art practice teaching activities, the current way of teaching mainly through the students to nature, scenery, ancient residential buildings such as modelling of sketch, color painting landscape sketch training, will learn the art theory of knowledge and skill of sublimation and improve performance. Through the color, the sketch courses teaching reform should pay attention to accumulation of internship students about Chinese building homes, local conditions and customs, natural scenery and cultural knowledge, deepen to the construction of excellent traditional culture deep and lay a solid all-round aesthetic cultivation for architectural design and drawing performance skills. In general, architecture art foundation course teaching to further strengthen students through multiple senses such as vision, hearing, touch sense art elements such as color and shape of object, accumulated construction related cultural history of the comprehensive professional knowledge, and form a comprehensive aesthetic consciousness, a kind of innovation ability, to lay a good foundation for the architecture speciality courses.

As an architect, it is very important to have a keen sense of form, and the process of painting is actually a process of cultivating observation ability. . In his "new drawing" Edward said: "although not to be a painter, but for those who want to use another half of the brain to perfect their own system of thinking and analysis ability, for those who want to use visual revelation or strategies to solve the problem of people, is a useful". Students in the observing object, through the observation of the eye, know the size of the object, scale, characteristics, the trained eye of perception and unarmed, after all, art is a practical strong discipline. As of today, we find the most suitable for freehand sketch capture the occasional flashes of inspiration thinking process, so we should enhance the ability of freehand sketch and strengthen the practice of literary sketch, and we are never simple sketch is probing into the records of lines and organization, in the record some modelling at the same time, the resulting lenovo should also be recorded in a timely manner, sketch practice also not only pursuit of surface beautiful, want to play the role of at any time to start thinking. At present some universities also is making a bold attempt to this aspect such as huazhong university of science and technology building art foundation curriculum reform will sketch course by the plaster, still life, landscape of the original three categories into creativity sketch, design drawings, structure drawings and so on five big classes, total amount of class time does not change, but become more rich content, technique of expression is also becoming more diverse. In the study of techniques, the expression space of individual creation and imagination is increased. The same is true for color courses. Therefore, the study and training of the techniques should be carried out to each link, rather than the bold speculation and unwarranted rhetoric of the "low hand". Therefore, the basic teaching of architecture art should not only pay attention to the theory, but also strengthen the training of practical techniques, and respect the law of modern art teaching.

\subsection{Expand the teaching form}

Due to the lack of cultural architecture speciality setting in universities of science and art atmosphere, the characteristics of the fine arts foundation course setting is shown by rigorous logic, strong theoretical, form a single, lack of interest. The art foundation course needs to establish a broad education space and actively carry out the second aesthetic education class. According to the situation of the current foundation education of fine arts, need to actively with the aid of campus cultural activities as the carrier, the common excavation of rich and colorful art activities, meet the demand of students of art appreciation and experience, promote students' aesthetic temperament and accomplishment. The development of basic art teaching can include art exhibitions, academic lectures and academic seminars. The art exhibition will collect works through the competition of art works in and out of school, and finally communicate with art works in the form of art exhibition. The 
academic lecture will create a good academic exchange environment by inviting professional and authoritative artists to give lectures on academic series. Academic seminars invite outstanding artists and professional teachers and students to answer face-to-face questions. Expanding the basic teaching form of art can provide students with an exchange platform and stimulate students' interest in learning. Can provide students with and create artistic practice platform, foster innovative thinking mode; Can be aesthetic education and the mutual infiltration with moral education, intellectual education, edify people's sentiment, mold a good heart.

\subsection{Modern education technology.}

The multimedia teaching method has been popularized in education in colleges and universities, and the knowledge information transmitted to students by limited means such as books, pictures and videos in the traditional teaching mode is supplemented with high efficiency and comprehensive. Modern education technology is flexible, interactive and convenient, and can impart professional knowledge via text, voice, picture, video, $3 \mathrm{~d}$ virtual animation and other information carriers. Architecture art foundation education through modern multimedia teaching means to innovate the traditional teaching model potential in the win. Teaching in teaching of traditional fine arts foundation technique through the use of modern education technology greatly improve the efficiency of teaching, break the method of demonstration teaching for a long time of single teaching mode, through pictures, music, video, fully mobilize students' visual and auditory sensory experience. The combination of education and modern teaching technology strengthens students' understanding and experience of art, and improves their interest in learning. On the other hand, it creates a good learning atmosphere, broadens the access to knowledge, greatly improves the learning effect, and improves students' comprehensive cultural knowledge and accomplishment.

\subsection{Teaching evaluation standard.}

Sound objective and scientific teaching evaluation standard can effectively mobilize students' interest in learning and increase the healthy learning competition among students. Traditional architectural art basic teaching middle school students often use the expression techniques as evaluation criteria, which is obviously too monotonous and does not conform to the scientific concept of art. The specialty of the art subject is special, and the evaluation and assessment of teaching results have certain subjectivity, so the evaluation result has great flexibility and randomness. The scientific teaching evaluation system respects the students' subjective value, pays attention to the development of students' individuality and creative thinking ability, and gives the objective orientation and evaluation of the teaching results. Architecture art education teaching evaluation standard of innovation should be to cultivate students the power to appreciate beauty and create beauty, transfer beauty as the goal, according to their aptitude, for further learning professional knowledge, laying a solid foundation for the art accomplishment of architecture. The scientific teaching evaluation criterion should pay attention to individuality and pursue an artistic aesthetic experience rather than just an objective imitation, an idea rather than a pattern, and a process is not a result. The teaching evaluation form should be diversified and enriched, and the evaluation system of multi-level evaluation should be established. For example, you can increase students in teachers' evaluation on the basis of evaluation model, lets the student directly involved in the teaching achievement evaluation process, fully open, flexible, further broaden the students' learning space and learning mode.

\subsection{Improve the quality of teachers and construct the characteristic teaching mode.}

In art teaching, the quality of teachers is very important. Whether teachers can play their leading role and create fitness.It is the key to the all-round development of students. First of all, teachers should keep abreast of The Times. The trend of exhibition and social progress cannot be based on a ready-made, unchanging teaching model.Professional curriculum setting, professional development direction, making teaching methods. According to professional adjustment, especially .Raise the goal and the change of the training mode, the professional curriculum setting, make the teaching method. With the quality education.

The development of the students before the entrance of the art foundation is higher and higher, in the comprehensive art capacity also has a larger.The improvement of new teaching methods should 
be actively explored for new problems. Teachers should keep learning.Adapt to the development of new situation, constantly improve self-cultivation, constantly absorb new knowledge, new ideas, constantly.Adjust the knowledge structure so that the students can study hard, learn easily and happily, and fill the art teaching with color and energy.

\section{Summary}

The students of architecture majors in universities require the basic knowledge of fine arts, which has become the consensus in the study of architecture major. In the traditional architecture art education in our country, pay attention to skill teaching and ignore the knowledge, single teaching mode of thinking, emphasizes the teaching of perceptual description and the lack of rational, this is the ordinary university architecture speciality the drawbacks in the teaching of art. In the face of a new round of education curriculum reform background, the art of architecture in common colleges and universities teaching should also be meaningfully to explore, to meet the needs of social progress and the development of contemporary science and technology, to the construction of architectural discipline. And to pay attention to visual arts education and teaching contents to pay attention to visual arts education of self-expression as total framework of architectural education of fine arts, for the ordinary university architecture speciality visual art education reform to do a new attempt, helps to cultivate talents and the development of the discipline of architecture. The following basic conclusions can be drawn from the above research:

Firstly, improving the art quality of students' artistic quality education is the effective teaching mode to solve the substantive problems. "A great workman is a man who rules and does not make a skillful man." The technique is not simple technical skill, the definition of skill should have more connotation and extension. "To write poetry, beyond poems," a still life and landscape sketches, should make students produce what kind of conception and creation passion, to achieve the purpose of training students' skill, understanding, and they of the influence of the theory training is necessary. "Tens of thousands of these, square as its true", broaden the content and scope of art teaching. Such as introduce students to the master of arts, ancient and modern, Chinese and foreign analysis and appreciation of their work, including understand master of art creation ideas, unique feeling, guides the student to express yourself cultivate students' common scene in the painting process become extraordinary art object, try to use different natural vivid expression to the lingering feeling appear colorful. The diversity of artistic expression and method makes students' aesthetic tendency and aesthetic understanding appear diverse. Organically mix the objective reappear and subjective performance, so as to achieve the creation of a new and sublimate the realm, which requires the students constantly strengthening the artistic accomplishment at ordinary times, cultivate a strong sense of creation, not only stay in the general level of skills training.

The second, popularize the art foundation education, enhance the specialty education, and teach the students according to their ability. Due to the quality of personal, family environment, especially the day after tomorrow and the living environment of the difference is very big, each of the students in intelligence, emotion, temperament and character, there are large individual differences. Therefore, varies from person to person, according to their aptitude, respect their objective existence of individual differences, causes the student to obtain the corresponding level and the requirements of the teaching guidance, let them get their own special abilities of the full performance opportunities, only in this way, students' individual character to play to the earth. As students' personalities and talents are different, students' descriptions of the same object often show colorful pictures. There is a personality of publicity, the imagination is rich, creation bold and bold, but lack of rigorous, quiet life characteristics. He is introverted, earnest and meticulous, but he is rigorous and lacks the spirit. More obvious personality like this, the teacher should be targeted for teaching guidance, should respect personality, and rational guidance, let them fully realized their strengths and advantages, help them establish self-confidence, foster strengths and circumvent weaknesses, make them jump out of the building, put more enthusiasm in learning the art, produce more interest. 
Thirdly, the cultivation of students' innovative thinking is the fundamental purpose of art teaching. From the elaboration of the previous training objectives, we clearly know that the teaching purpose of architecture major in the undergraduate stage is to cultivate innovative thinking and innovative design talents. For designers, innovation is their lifelong pursuit. Always for a long time, the fine arts teaching the knowledge and skills as the main body of education, especially the technique ability training almost is the core content of teaching, and formed a fixed set of skills training mode, also more increased teaching evaluation system to remove code. Skill training is of extreme importance to skillfully express image information, it is generally accepted that the facts, but the training methods of cultivating students' innovative thinking must with master synchronization technique, can achieve the purpose of art teaching. Einstein once said, "imagination is more important than knowledge." Therefore, we should strengthen the imagination in the fine arts curriculum training, achieve the goal of cultivating creative thinking through this training, exert students' subjective initiative, create greater space for the students' innovative thinking practice and platform, providing multiple evaluation system. Teaching reform is a complex system project with directionality, overall and pioneering work. Out of the narrow sense of architecture. On the education target, we should emphasize training with extensive knowledge, solid basic skills, a high degree of cultural quality and artistic accomplishment, strong comprehensive ability, to participate in international competition of the future architectural talents. In education mode, we emphasize the importance of education teaching reform, update teaching content and improve teaching methods. Summarizes the nearly hundred years development of Chinese modern architectural education experience, absorb the architecture development, set up to adapt to the socialist market economy of Chinese architectural art new curriculum system, combined with the development of the regional architecture, encourage diverse and distinctive education mode exploration; In the future, we will continue to study the curriculum setting and teaching methods of this specialty, and comprehensively promote the basic teaching reform of architecture specialty.

\section{References}

[1]. Shu Wang, To build a house. Hunan fine arts press,2016, p.18-35.

[2]. Zhongyi Wang, Jiang Xu, From sketch to design. China academy of fine arts press, 2002, p. 21-88.

[3]. Shunyao Nan,Huaquan Xin,The architectural composition.China construction press,1999, p. 21-30. 